\title{
The Impact Of Extrinsic Motivational Dissatisfiers On Employee Level Of Job Satisfaction And Commitment Resulting In The Intent To Turnover \\ Michael Pepe, Siena College, USA
}

\begin{abstract}
This study examines the relationship between Extrinsic motivational factors such as Perceived Supervisor Support (PSS) and job satisfaction, organizational commitment and the intent to leave. Using a sample of 46 managers and clerical support staff at a Supermarket retailer, the findings indicate that as employees' perception of Supervisor Support increases, their organizational commitment (affective and continuance) and job satisfaction significantly increase. Also, as employee organizational commitment (affective and continuance) and job satisfaction increase, their intent to leave significantly decreases.
\end{abstract}

Keywords: Extrinsic Motivation, Perceived Supervisor Support, Job Satisfaction, Organizational Commitment, Intent to Leave

\section{INTRODUCTION}

n today's competitive and global environment, businesses must not only have a winning business model, they also must have winning employees. The most valuable asset that any company has is its people. You're only as good as your people and the war for talent is intense (Fitz-enz, 1997). Business executives are becoming increasingly concerned with the costly challenges of locating, attracting and, most importantly, retaining quality employees. American business executives are more concerned about a shortage of skilled labor than about global competition (Wagner, 1994).

Managers must be cognizant of the effect that working conditions have on employee job satisfaction and commitment levels since there is significant economic impact with an organization losing any one of its critical employees. Combined with direct and indirect costs, the total cost of employee turnover is a minimum of one year's pay and benefits, or a maximum of two years' pay and benefits (Fitz-enz, 1997). 58\% of organizations claim that they are experiencing difficulty retaining their employees (Hale, 1998). The challenge, then, is to develop a corporate culture that is extrinsically rewarding resulting in a workforce of highly satisfied, affectively committed workers.

Companies strive to develop a workforce of committed employees based on the belief that organizations with committed employees achieve superior long-term performance (Luchak \& Gellatly, 2007). Committed employees are characterized as loyal, productive members of work organizations (Porter, Steers, Mowday \& Boulian, 1974) who identify with organizational goals and values (Buchanan, 1974). Employees attach to their organizations emotionally as they come to believe in its value and vision (Mulki, Jaramillo \& Locander, 2006). The notion of commitment has been broken down into three levels: affective, continuance, and normative. Ideally for organizations, employees will have an affective level of commitment. Affective commitment refers to the employee's emotional attachment to, identification with, and involvement in the organization. Employees with a strong affective commitment continue employment with the organization because they want to do so. Continuance commitment refers to awareness of the costs associated with leaving the organization. Employees that exhibit 
continuance commitment remain with an organization because they need to do so. Finally, normative commitment refers to employees that feel they ought to remain with the organization (Meyer \& Allen, 1991).

A wide array of desirable behavioral outcomes has been linked to work-related commitment including: employee retention, job performance, attendance, work quality, and personal sacrifice on behalf of the organization (London, 1983). Steers (1983b) reported a substantial negative relationship between organizational commitment and voluntary turnover. Meyer and Allen (1991) also noted a negative relationship between organizational commitment and intent to turnover.

A recent meta-analysis indicates that affective commitment to the organization is positively related to job performance (Mathieu \& Zajac, 1990). Employees' emotional bond to their organizations (affective commitment) has been considered an important determinant of dedication and loyalty. Affectively committed employees are seen as having a sense of belonging and identification that increases their involvement in the organization's activities, their willingness to pursue the organization's goals, and their desire to remain with the organization (Meyer \& Allen, 1991). There have also been associations between affective commitment and absenteeism, performance, and turnover ( Meyer \& Allen, 1997). Regarding antecedents of affective commitment, Meyer and Allen (1997) found that work experiences such as organizational rewards, procedural justice, and supervisor support have demonstrated stronger associations with affective commitment than have structural features of the organization or personal characteristics of employees.

Perceived organizational support (POS) is characterized by employees' general beliefs concerning how much the organization cares about their well-being (Rhoades, Eisenberger \& Armeli, 2001). POS is encouraged by employees' tendency to ascribe humanlike characteristics to the organization. Because employees personify the organization, they view favorable or unfavorable treatment as indicative of the organization's benevolent or malevolent orientation toward them (Eisenberger et al., 1986). Favorable work experiences were associated with POS to the extent that employees believed they were under the organization's voluntary control. Eisenberger et al. (1986) found that the relationship between perceived organizational support and affective commitment was partly mediated by employees' felt obligation to care about the organization's welfare and help the organization reach its goals.

Reliable relationships have been reported between supervisor support and perceived organizational support and between POS and AC (Hutchinson, 1997). Affective commitment was also found to be associated with additional measures of supportive and caring treatment by employees' supervisors (Bycio, Hackett, \& Allen, 1995).

Closely related to commitment is job satisfaction. Work satisfaction is defined as one's sense of satisfaction not only with the work itself but also with the larger organizational context within which work exists (Bussing et al., 1999). Job satisfaction is more narrowly defined as "a pleasurable or positive emotional state resulting from the appraisal of one's job or job experiences" (Locke, 1976). Although closely related, work and job satisfaction may not be the same thing.

There has been extensive research to understand the relationship between job satisfaction and organizational commitment. Porter et al. (1974) identified work satisfaction as the antecedent of commitment, a theory supported by (Williams \& Hazer, 1986). Affective and continuance commitment were found to correlate positively with job satisfaction (Meyer et al., 1993).

Participatory management practices balance the involvement of managers and their subordinates in information-processing, decision-making, or problem-solving endeavors (Wagner, 1994). Several studies have demonstrated that participative decision making can be beneficial to workers' job satisfaction (Spector 1986, Miller \& Monge 1986). Organizational leaders' commitment to changing organizational culture from the traditional patterns of hierarchical structure to participative management and empowerment should be emphasized (Kim, 2002).

Job satisfaction plays an important role in measuring the intent to turnover and is consistently found to be negatively related to intent to leave. Job dissatisfaction stimulates thoughts of leaving, which leads the individual to evaluate the expected utility of search, intention to search, the search itself, evaluation of alternatives, intention to 
quit, and finally the withdrawal decision and behavior (Arnold \& Feldman, 1982). Job satisfaction is an attitudinal cause of commitment and is, therefore, important to the study of organizational commitment and turnover. DeCotis et al. (1987) also show that job satisfaction is an antecedent of organizational commitment.

Herzberg's (1966) two-factor theory has discussed satisfiers and dissatisfiers. Based on his research, Herzberg discovered that employees tended to describe satisfying experiences in terms of factors that were intrinsic to the content of the job itself. These factors were called "motivators" and included such variables as achievement, recognition, the work itself, responsibility, advancement, and growth. In essence, there are more to a manager's role in motivating employees other than compensation, good working conditions, and similar factors. Herzberg argued that for an employee to be truly motivated, the employee's job has to be fully enriched where the employee has the opportunity for achievement and recognition, stimulation, responsibility, and advancement (Ramiall, 2004).

Herzberg's External Hygiene factors such as the relationship with the boss, job security, interpersonal relations and pay can be dissatisfiers. Eliminating the causes of dissatisfaction through hygiene factors will not result in a state of satisfaction but in a neutral state. Satisfaction and motivation will only occur as a result of the use of motivators. Motivation can be increased through basic changes in the nature of an employee's job through job enrichment. Thus, jobs should be redesigned to allow for increased challenge and responsibility, opportunities for advancement and personal growth, and recognition (Steers, 1983).

Employees develop general views concerning the degree to which supervisors value their contributions and care about their well-being. This is known as perceived supervisor support or PSS (Kotte \& Sharafinski, 1988). There has been a positive relationship between perceived supervisor support (PSS) and perceived organization support (POS) (Rhoades et al., 2001). Employees who believe that their supervisor(s) value their contributions and care about their well-being show increase POS, which in turn relates to decreased turnover. This finding is consistent with organizational support theory which holds that beneficial treatment received from supervisors should lead to a felt obligation to aid the organization and to affective organizational commitment, both of which should reduce turnover (Rhoades at al., 2001). Therefore, the following hypotheses are proposed.

Hypothesis 1: There is a significant positive relationship between Perceived Supervisor Support and Job Satisfaction

Hypothesis 2: There is a significant positive relationship between Perceived Supervisor Support and Affective Commitment

Hypothesis 3: There is a significant positive relationship between Perceived Supervisor Support and Continuance Commitment

Hypothesis 4: There is a significant negative relationship between Job Satisfaction and Intent to Leave

Hypothesis 5: There is a significant negative relationship between Affective Commitment and Intent To Leave

Hypothesis 6: There is a significant negative relationship between Continuance Commitment and Intent To Leave

\section{METHODOLOGY}

To test the hypotheses, employees at corporate headquarters from a Supermarket chain were used. A selfadministered survey was used for gathering data in this study as respondents received the survey via their home mail. Each participant received a research packet containing the following: (1) A cover letter stating the purpose of the survey, (2) the survey and (3) a large self-addressed and stamped envelope.

Subjects were asked to complete demographic questions as well as questions pertaining to their work environment. Each respondent, upon completion of the survey, put the results in the self-addressed envelope, sealed it, and mailed it back to the researchers' home address anonymously. Each respondent was allowed two weeks to complete and return the survey to the researcher. 


\section{Sample}

The sample consisted of 46 full-time employees categorized by either managers ( $n=17)$ or clerical support $(\mathrm{n}=29)$. The number of males was $19(53 \%)$ and the number of females was $27(47 \%)$. The management group consisted of 12 males (71\%) and the clerical support group was comprised of 19 males (66\%). The average tenure of the subjects with the organization was 6.14 years $($ s.d. $=5.778)$ and their average tenure with their current supervisor was 2.81 years $(\mathrm{s} . \mathrm{d} .=1.616)$.

Table I shows the Age and Educational Levels of the sample, measured as categorical variables:

Table I

Age * Education Crosstabulation

Count

\begin{tabular}{|c|c|c|c|c|c|c|c|}
\hline & \multicolumn{5}{|c|}{ Education } & \multirow[b]{2}{*}{ Total } \\
\hline & & High School & $\begin{array}{c}\text { Associate's } \\
\text { degree }\end{array}$ & $\begin{array}{c}\text { Bachelor's } \\
\text { Degree }\end{array}$ & Master's Degree & $\begin{array}{c}\text { Post-Master's } \\
\text { Work }\end{array}$ & \\
\hline \multirow[t]{5}{*}{ Age } & Under 26 & 4 & 1 & 1 & 0 & 0 & 6 \\
\hline & 26 to 35 & 8 & 2 & 3 & 0 & 0 & 13 \\
\hline & 36 to 45 & 5 & 3 & 6 & 3 & 2 & 19 \\
\hline & 46 to 55 & 3 & 1 & 3 & 0 & 0 & 7 \\
\hline & 56 to 65 & 0 & 0 & 1 & 0 & 0 & 1 \\
\hline \multicolumn{2}{|c|}{ Total } & 20 & 7 & 14 & 3 & 2 & 46 \\
\hline
\end{tabular}

\section{MEASURES}

\section{Organizational Commitment}

Mowday, Porter and Steers (1982) defined commitment as the relative strength of an individual's identification with and involvement in a particular organization, which is characterized by a belief in the goals and values of the organization, a willingness to exert effort on behalf of the organization and a strong desire to remain with the organization. Meyer and Allen (1991) suggested that each component of commitment develops independently of each other as a function of different antecedents in developing their three-component model. This model has been validated for its psychometric characteristics and demonstrates a good internal consistency of reliability (Hackett, Bycio \& Hausdorf, 1994).

For this study, organizational commitment was measured by affective and continuous commitment. The Affective Commitment Scale (ACS) and Continuance Commitment Scale (CCS) are instruments consisting of questions that measure each type of commitment. Affective commitment was measured with 6 items developed by Meyer et al. (1990) and modified by Rhoades et al. (2001). Continuance commitment was measured with the 8-item instrument from Meyer et al. (1990). The scale used for this survey is a five point Likert Scale ranging from Strongly Disagree (1) to Strongly Agree (5). This study produced a Cronbach's alpha of .8592 for Affective Commitment and .7944 for Continuance Commitment. This is consistent with previous research that resulted in a Cronbach's alpha of .84 to .88 for Affective Commitment and .70 to .84 for Continuance Commitment (Meyer et al., 1989). Therefore, the scales have demonstrated that they possess a high degree of internal validity and reliability. A copy of the survey sent to respondents is provided in the appendix.

\section{Job Satisfaction}

Job satisfaction is defined as the extent of the positive affective orientation toward a job (Bluedorn, 1982). Job satisfaction has been approached as a concept that concerns only an employee's overall feelings about the job, not the employee's behavior toward the job (lateness, absenteeism, etc.). Job satisfaction plays an important role in 
measuring the intent to turnover (Arnold \& Feldman, 1982) and is consistently found to be negatively related to intent to leave. In this study, job satisfaction was measured using components of the Minnesota Satisfaction Questionnaire (MSQ) short form developed by Weiss et al., (1967). The MSQ measures different attributes of an organization with internal components using a five point Likert-scale ranging from strongly disagree (1) to strongly agree (5). Questions from the MSQ used for this study concentrated on Supervisor-Human Relations aspect of job satisfaction and consisted of six questions. The results of this study produced a Cronbach's alpha of 9062 for job satisfaction. This is consistent with previous research which reported a range of internal reliability coefficients of .87 to .92 (Cook, Hepworth, Wall, \& Warr, 1981).

\section{Perceived Supervisor Support}

Employees develop general views concerning the degree to which supervisors value their contributions and care about their well-being. This is known as perceived supervisor support or PSS (Kotte \& Sharafinski, 1988). Employees who believe that their supervisor(s) value their contributions and care about their well-being show increase POS, which in turn relates to decreased turnover. This finding is consistent with organizational support theory which holds that beneficial treatment received from supervisors should increase POS, leading to felt obligation to aid the organization and to affective organizational commitment, both of which should reduce turnover (Rhoades et al., 2001; Maertz et al., 2007).

The Survey of Perceived Supervisor Support (Eisenberger et al., 2002) was used to measure perceived supervisor support in this study using a five point Likert scale ranging from strongly disagree (1) to strongly agree (5). The nine item scale produced a Cronbach's alpha of .9163 for this research. Questions three and eight were reverse scored so that higher scores are an indication of higher perceived supervisor support. An internal consistency of .92 has been found using this survey.

\section{Intent To Leave}

Intent to leave is the measure of the likelihood that the individual will leave the organization. The Intent to Leave Index scale is an instrument that uses a 5-point Likert-type scale ranging from 1 (strongly disagree) to 5 (strongly agree). As previously mentioned, Reliability is a reflection of the internal consistency of a measure based on the average correlation among items within a scale. The three item scale for this study produced a Cronbach's alpha of .8485. Alpha coefficients were .80 in samples used in Jaros' study (1995).

\section{RESULTS}

Descriptive statistics for all variables used in the study are shown in Table II and intercorrelations are displayed in Table III.

\begin{tabular}{lccc}
\multicolumn{1}{c}{ Variable } & $\begin{array}{c}\text { Table II: Descriptive Statistics } \\
\text { Mean }\end{array}$ & Standard Deviation & Cronbach's Alpha \\
\hline Perceived Supervisor Support & 3.11 & .70 & .92 \\
Affective Commitment & 2.94 & .67 & .86 \\
Continuous Commitment & 3.26 & .52 & .79 \\
Job Satisfaction & 3.02 & .59 & .91 \\
Intent to Leave & 3.23 & 1.18 & .85 \\
\hline
\end{tabular}


Table III: Intercorrelations

\begin{tabular}{|c|c|c|c|c|c|c|}
\hline \multicolumn{7}{|c|}{ Correlations } \\
\hline & & $\begin{array}{c}\text { Perceived } \\
\text { Supervisor } \\
\text { Support }\end{array}$ & $\begin{array}{c}\text { Affective } \\
\text { Commitment }\end{array}$ & $\begin{array}{l}\text { Continuous } \\
\text { Commitment }\end{array}$ & $\begin{array}{c}\text { Job } \\
\text { Satisfaction }\end{array}$ & $\begin{array}{l}\text { Intent To } \\
\text { Leave }\end{array}$ \\
\hline \multirow{3}{*}{$\begin{array}{l}\text { Perceived Supervisor } \\
\text { Support }\end{array}$} & Pearson Correlation & 1 & $.893^{* *}$ & $.857^{* * *}$ & $.857^{* * *}$ & $-.796^{* *}$ \\
\hline & Sig. (2-tailed) & & .000 & .000 & .000 & .000 \\
\hline & $\mathrm{N}$ & 44 & 43 & 43 & 43 & 43 \\
\hline \multirow{3}{*}{\begin{tabular}{|l} 
Affective \\
Commitment
\end{tabular}} & Pearson Correlation & $.893^{* *}$ & 1 & $.817^{* *}$ & $.804^{* * *}$ & $-.741^{* *}$ \\
\hline & Sig. (2-tailed) & .000 & & .000 & .000 & .000 \\
\hline & $\mathrm{N}$ & 43 & 45 & 44 & 44 & 44 \\
\hline \multirow{3}{*}{$\begin{array}{l}\text { Continuous } \\
\text { Commitment }\end{array}$} & Pearson Correlation & $.857^{* *}$ & $.817^{* *}$ & 1 & $.829^{* * *}$ & $-.704^{* *}$ \\
\hline & Sig. (2-tailed) & .000 & .000 & & .000 & .000 \\
\hline & $\mathrm{N}$ & 43 & 44 & 45 & 44 & 44 \\
\hline \multirow[t]{3}{*}{ Job Satisfaction } & Pearson Correlation & $.857^{* *}$ & $.804^{* *}$ & $.829^{* * *}$ & 1 & $-.756^{* *}$ \\
\hline & Sig. (2-tailed) & .000 & .000 & .000 & & .000 \\
\hline & $\mathrm{N}$ & 43 & 44 & 44 & 45 & 44 \\
\hline \multirow[t]{3}{*}{ Intent To Leave } & Pearson Correlation & $-.796^{* *}$ & $-.741^{* * *}$ & $-.704^{* *}$ & $-.756^{* *}$ & 1 \\
\hline & Sig. (2-tailed) & .000 & .000 & .000 & .000 & \\
\hline & $\mathrm{N}$ & 43 & 44 & 44 & 44 & 45 \\
\hline
\end{tabular}

Hypothesis 1 stated that there is a significant relationship between Perceived Supervisor Support and Job Satisfaction. The results indicate that there is a significant positive correlation $(r=.857 ; \mathrm{p}<.01)$ between Perceived Supervisor Support and Job Satisfaction (see Table III). Therefore, Hypothesis 1 is supported.

Hypothesis 2 stated that there is a significant relationship between Perceived Supervisor Support and Affective Commitment. The results indicate that there is a significant positive correlation $(r=.893 ; \mathrm{p}<.01)$ between Perceived Supervisor Support and Affective Commitment (see Table III). Therefore, Hypothesis 2 is supported.

Hypothesis 3 stated that there is a significant relationship between Perceived Supervisor Support and Continuance Commitment. The results indicate that there is a significant positive correlation $(r=.857 ; \mathrm{p}<.01)$ between Perceived Supervisor Support and Continuance Commitment (see Table III). Therefore, Hypothesis 3 is supported.

Hypothesis 4 stated that there is a significant negative relationship between Job Satisfaction and Intent to Leave. The results indicate that there is a significant negative correlation $(r=-.756 ; p<.01)$ between Job Satisfaction and Intent to Leave (see Table III). Therefore, Hypothesis 4 is supported.

Hypothesis 5 stated that there is a significant negative relationship between Affective Commitment and Intent To Leave. The results indicate that there is a significant negative correlation $(r=-.741 ; p<.01)$ between Affective Commitment and Intent To Leave (see Table III). Therefore, Hypothesis 5 is supported.

Hypothesis 6 stated that there is a significant negative relationship between Continuance Commitment and Intent To Leave. The results indicate that there is a significant negative correlation $(r=-.704 ; \mathrm{p}<.01)$ between Continuance Commitment and Intent To Leave (see Table III). Therefore, Hypothesis 6 is supported.

\section{DISCUSSION}

The results of this study are significant because they demonstrate a positive relationship between extrinsic motivational factors such as perceived supervisor support and employee commitment and job satisfaction levels. For 
organizations to develop a work force consisting of highly committed, satisfied employees, managers must demonstrate a high level of support toward their associates. In the present study, a low level of perceived supervisor support resulted in a low level of employee organizational commitment and job satisfaction. This positive relationship implies that increasing supervisor support may increase employee organizational commitment and job satisfaction.

The research findings of a negative relationship between (1) organizational commitment and intent to leave and between (2) job satisfaction with intent to leave are significant because of the importance of retaining personnel. Beneficial treatment received from supervisors should lead to increased organizational commitment and job satisfaction, both of which should reduce turnover. Employee retention is important in realizing a full return on investment. Organizations will need to either create an intellectual capital environment in which the transmission of knowledge takes place throughout the structure, or continue to lose important individual knowledge that has been developed through the length of service. This deep knowledge is what many believe will help to meet the needs and expectations of the customers and to create and sustain a competitive advantage within the global economy in which organizations are competing today.

The numerous demands of today's technologically fast-paced business world necessitate organizations to retain top caliber personnel (Wagner, 1994). Developing a committed work force comprised of highly task-oriented employees will dramatically increase the quality and efficiency of product and service offerings to customers. External work factors such as supervisor relations, pay, co-worker relations and organization culture significantly influence employee satisfaction and commitment to the company and must be monitored to ensure that these factors impact employees in a positive manner to ensure a high level of retention.

There are some potential limitations to this study that must be considered. One limitation of this study is the respondents taking the survey in their home environment. This setting may pose a vast array of distractions and cause the subjects to lack focus in responding. Another limitation is that the researcher is a co-worker of the respondents. This may cause researcher, as well as respondent, bias in the study although the responses were both anonymous and confidential. Also, the population consists of only 46 participants. A larger sample size may prove to result in a more accurate statistical level of reliability.

Managers must be cognizant of the support they give to their employees. A high level of supervisor support positively correlates with a high level of organizational commitment and job satisfaction which, in turn, reduces the level of employee voluntary turnover. This research identified that perceived supervisor support is an important factor in determining organizational commitment and job satisfaction. This study demonstrated that when employees perceive their supervisors offering little support, their commitment and job satisfaction decreases. It is also important for organizations to know that less committed and satisfied workers have less attachment to their organizations and intend to leave. Thus, organizations need to be aware of workers' needs and support them.

The implications of this study can contribute to academic researchers as well as business managers. There are several directions future research might take. The first direction would be to repeat this study with a larger number of employees. The population size of forty-six did not represent a large, diverse population size. Also, various industrial types and geographic locations can be explored and analyzed with a larger sample.

Employees in this study showed that their perceived supervisor support significantly related to their organizational commitment and job satisfaction. Future research should concentrate on other extrinsic motivational factors such as perceived organizational support, pay or job security. The results not only contribute to understanding of the implications of extrinsic motivational factors on employee commitment, job satisfaction and intent to leave but also provide practical implications for managers. Future research designed to address the limitations of this study should provide even greater understanding of the organizational impact of perceived supervisor support on organizational commitment and job satisfaction and intent to leave. 


\section{AUTHOR INFORMATION}

Michael Pepe is an Assistant Professor of Marketing and Management at Siena College in Loudonville, NY. After 20 years as a business professional in the retailing industry he became a full-time faculty member at Siena in 2009. His research interests include branding, consumer behavior, and pricing strategies. He has presented papers at the College Learning and Teaching Conference and Applied Business and Research Conference.

He currently is the American Marketing Association student advisor at Siena College.

\section{REFERENCES}

1. Arnold H.J., \& Feldman DC. (1982). A multivariate analysis of the determinants of job turnover. Journal of Applied Psychology, 67, 350-360.

2. Bluedorn, A.C..(1982). A unified model of turnover from organizations. Human Relations, 35, 135-153.

3. Buchanan, B. (1974). Building organizational commitment: the socialization of managers in work organizations. Administrative Science Quarterly, 19, 533-546.

4. Bussing, A., Bissels, T., Fuchs, V. \& Perrar K.-M. (1999). A dynamic model of work satisfaction: qualitative approaches, Human Relations, 52,(8), 999-1028.

5. Bycio, P., Hackett, R.D., \& Allen, J. S. (1995). Further assessments of Bass's (1985) conceptualization of transactional and transformational leadership. Journal of Applied Psychology, 80, 468-478.

6. Cook, J.D., Hepworth, S.J., Wall, T.D., \& Warr, P.B. (1981). The Experience of Work: A Compendium and Review of 249 Measures and their use (Academic Press, London).

7. DeCotis, T. \& Summers, T. (1987). A path analysis of a model of the antecedents and consequences of organizational commitment. Human Relations, 40, 445-470.

8. Eisenberger,R., Huntington, R., Hutchinson, S., \& Sowa, D. (1986). Perceived Organizational Support. Journal of Applied Psychology, 71, 500-507.

9. $\quad$ Eisenberger, R., Stinnglhamber, F., Vandenberghe, C., Sucharski, I., \& Rhoades, L. ( 2002). Perceived Supervisor Support: Contributions to Perceived Organizational Support and Employee Retention. Journal of Applied Psychology, 87, 565-573.

10. Fitz-enz, J. (1997). It's costly to lose good employees. Workforce. 50.

11. Hackett, R. D., Bycio, P., \& Hausdorf, P. A. (1994). Further assessments of Meyer and Allen's (1-991) three-component model of organizational commitment. Journal of Applied Psychology, 79, 15-23.

12. Hale, J. (1998). Strategic Rewards: Keeping your best talent from walking out the door. Compensation \& Benefits Management. 14(3), 39-50.

13. Hergberg, F. (1966). Work and the nature of man. Cleveland: World.

14. Hutchinson, S. (1997). A path model of perceived organizational support. Journal of Social Behavior and Personality, 12, 159-174.

15. Jaros, S. (1995). An assessment of Meyer and Allen's (1991) three-component model of organizational commitment and turnover intentions. Academy of Management Journal, 14, 317-322.

16. Kim, S. (2002). Participative management and job satisfaction: Lessons for management leadership. Public Administration Review, 62, 231-241.

17. Kottke, J. L., \& Sharafinski, C. E. (1988). Measuring perceived supervisory and organizational support. Educational and Psychological Measurement, 48, 1075-1079.

18. Locke, E.A. (1976). The nature and causes of job satisfaction, in Dunnette, M.D.(Ed.). Handbook of Industrial and Organizational Psychology, Wiley, New York,NY,pp.1297-351.

19. London, M. (1983). Toward a theory of career motivation. Academy of Management Review, 8, 620-630.

20. Luchak, A. \& Gellatly, I. (2007). A Comparison of Linear and Nonlinear Relations Between Organizational Commitment and Work Outcomes. Journal of Applied Psychology, 92(3), 786-793.

21. Maertz, C., Griffeth, R., Campbell, N., \& Allen, D. (2007). The Effects of Perceived Organizational Support and Perceived Organizational Support on Employee Turnover. Journal of Organizational Behavior, 28(8), 1059-1075.

22. Meyer, J. P.; Allen, N. J., \& Gellatly, I. R. (1990). Affective and continuance commitment to the organization: Evaluation of measures and analysis of concurrent and time-lagged relations. Journal of Applied Psychology, 75, 710-720. 
23. Meyer, J. \& Allen, N. (1997). Commitment in the Workplace. Thousand Oaks: Sage Publications.

24. Meyer, J. P., \& Allen, N. J. (1991). A three-component conceptualization of organizational commitment. Human Resource Management Review, 1, 61-89.

25. Meyer, J.P., Allen, N.J. \& Smith, C.A. (1993). Commitment to organizations and occupations: extension and test of a three-component conceptualization. Journal of Applied Psychology, 78(4), 538-51.

26. Meyer, J. P., Paunonen, S.V., Gellatly, I.R., Goffin, R.D., \& Jackson, D. (1989). Organizational commitment and job performance: It's the nature of commitment that counts. Journal of Applied Psychology, 74, 152-156.

27. Miller ,K \& Monge, P. (1986). Participation, Satisfaction, and Productivity: A Meta-Analytic Review. Academy of Management Journal, 4, 727-753.

28. Mowday, R. T., Porter, L. W., \& Steers, R. M. (1982). Employee-organization linkages: The psychology of commitment, absenteeism, and turnover. New York: Academic Press.

29. Mulki, J, Jaramillo, F., \& Locander, W. (2006). Effects of Ethical Climate and Supervisory Trust on Salesperson's Job Attitudes and Intention to Quit. Journal of Personal Selling \& Sales Management, 26(1), 19-26.

30. Porter, L., Steers, R., Mowday, R. \& Boulian, P. (1974). Organizational commitment, job satisfaction and turnover among psychiatric technicians. Journal of Applied Psychology, 59, 603-609.

31. Ramiall, Sunil. (2004). A Review of Employee Motivation Theories and Their Implications for Employee Retention within Organizations. Journal of American Academy of Business, Cambridge, 5, 52-64.

32. Rhoades, L, Eisenberger, R \&Armeli. (2001). Affective Commitment to the Organization: The Contribution of Perceived Organizational Support. Journal of Applied Psychology, 86, 825-836.

33. Spector, Paul E .(1986). Perceived Control by Employees: A Meta-Analysis of Studies Concerning Autonomy and Participation at Work. Human Relations,39, 1005-1016.

34. Steers, R., \& Porter, L. (1983b). Motivation and Work Behavior (Third ed.). New York: McGraw-Hill.

35. Wagner, John A. III.( 1994). Participation's Effect on Performance and satisfaction: A reconsideration of Research Evidence. Academy of Management Review, 19 (2), 312-330.

36. Weiss, D., Dawis. R., Lofquist,L. \&England, G. (1967). Manual for the Minnesota Satisfaction Questionnaire. Minneapolis: University of Minnesota.

37. Williams, L.J. \& Hazer, J.T. (1986). Antecedents and consequences of satisfaction and commitment in turnover models: a reanalysis using latent variable structural equation methods. Journal of Applied Psychology, 71(2), 219-31. 
NOTES 